\title{
Synthesis and Crystal Structure of Overcrowded Non-photochromic Organometallic Fulgide
}

\author{
Shar Saad Al-Shihry
}

Department of Chemistry, College of Science, King Faisal University, P.O.Box 1759, Saudi Arabia, Email: sshihry@kfu.edu.sa.

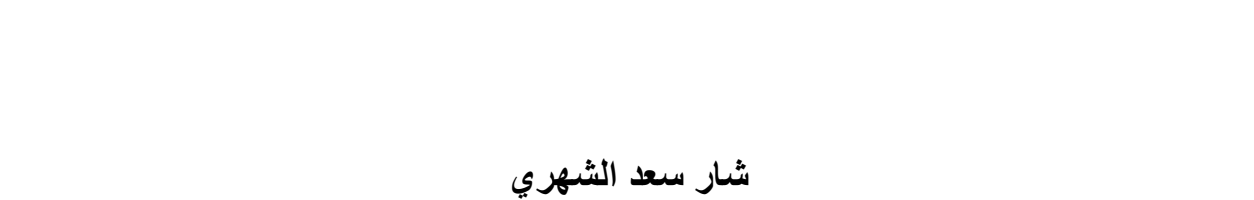

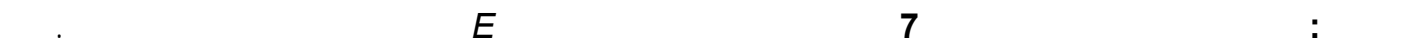

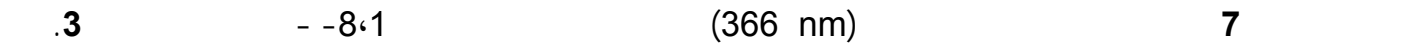

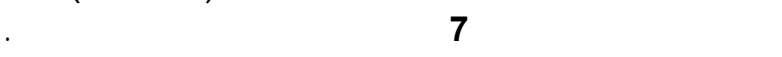

\begin{abstract}
Pure E-isomer overcrowded organometallic fulgide $\mathbf{1}$ was obtained by using successive Stobbe condensations between ketones and succinate diester. Upon irradiation with UV light at $(366 \mathrm{~nm})$ it did not cyclise photochemically to the 1,8a-dihydronaphthalene derivative (1,8aDHN) 8. The structure of 7 was confirmed by X-ray crystallographic analysis.
\end{abstract}

KEYWORDS: Fulgide, Stobbe Condensation, Organometallic, Crystal Structure.

\section{Introduction}

Gulgides with aryl ring undergo ring-closure photochemically to give highly coloured tricyclic dihydronaphthalene derivatives (Heller 1978). It was found that the preferred isomer was the E-isomer in sterically-hindered fulgide systems (Hart and Heller 1972; McCabe et al. 1993; Liang et al. 2001). McCabe et al. (1993) synthesized the first organometallic fulgide 1, which was obtained as $E$-isomer $\mathbf{1}$. Irradiation of $\mathbf{1}$ underwent $E / Z$ isomerization to $Z$-isomer $\mathbf{2}$ rather than ring-closure, despite the introduction of donating groups on the ferrocenyl moiety Scheme 1.

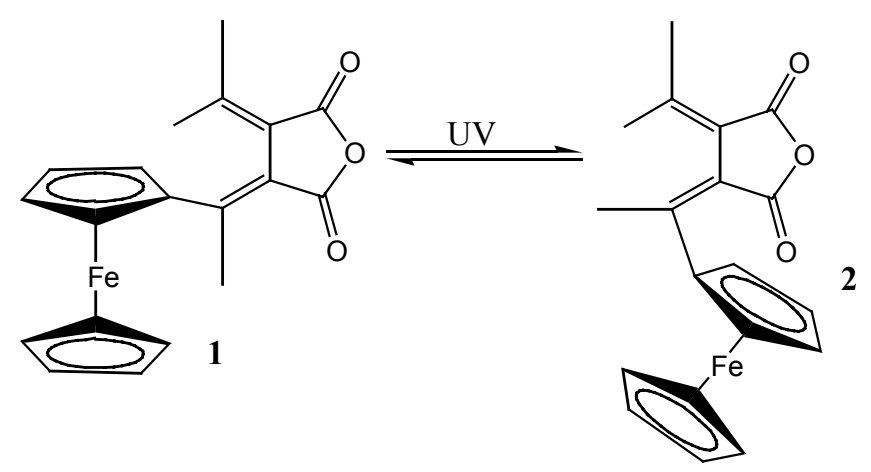

Scheme 1: $E / Z$ isomerization of fulgide 1 .

In the present work diphenylidene was introduced to the system to investigate whether or not photocyclization would occur, according to electrocyclization reaction, in agreement with Woodward-Hofmann rules (Yokoyama 2000). 


\section{SHAR SAAD AL-SHIHRY}

\section{Experimental}

General: Melting points were recorded on a Gallenkamp melting point apparatus and were uncorrected. NMR spectra were obtained in $\mathrm{CDCl}_{3}$ on a Jeol $400 \mathrm{MHz}$ with TMS as internal reference; chemical shifts were expressed in $\delta(\mathrm{ppm})$. Irradiation of the prepared fulgide in toluene at $366 \mathrm{~nm}$ for $48 \mathrm{hrs}$ was carried out, using UV lamp (UV GL-58, 254/366 nml lamp, 50/60 Hz), while UV-Visible double beam spectrophotometer (Shimadzu UV-1601PC) was used to follow up the irradiation effect.

Dimethyl (diphenylmethylene)succinate 4: A mixture of benzophenone (18.2 g, 0.1 moles), dimethyl succinate $(17.5 \mathrm{~g}, 0.12 \mathrm{moles})$ and potassium $t$-butoxide (12 g, 0.1 moles) in toluene (200 $\mathrm{ml}$ ) was stirred for 6 hours. Work-up produced the half ester, which was esterified to give the diester as yellow crystals $(17 \mathrm{~g}, 55 \%$ yield $)$ m.p. $78-79^{\circ} \mathrm{C} .{ }^{1} \mathrm{H}-\mathrm{nmr}: 3.46\left(2 \mathrm{H}, \mathrm{s}, \mathrm{CH}_{2}\right.$ proton $), 3.45$ $\left(3 \mathrm{H}, \mathrm{s}, \mathrm{CH}_{3} \mathrm{O}\right), 3.70\left(3 \mathrm{H}, \mathrm{s}, \mathrm{CH}_{3} \mathrm{O}\right), 7.10-7.40(10 \mathrm{H}, \mathrm{m}$, aromatic proton).

Ferrocenylethylidene (diphenylidene)succinic anhydride 7: Stobbe condensation on an equimolar basis of dimethyl (diphenylmethylidene) succinate ( $10 \mathrm{~g}, 0.03$ moles) and ferrocene (7.5 $\mathrm{g}, 0.03$ moles $)$ in toluene $(200 \mathrm{ml})$ in the presence of potassium $t$-butoxide, followed by hydrolysis of the half ester gave the diacid, which cyclised with acetyl chloride. The solvent and acetyl chloride were removed and the residue was dissolved in dichloromethane and chromatographed on silica gel to give the fulgide 7 as black crystals from dichloromethane and petroleum ether $(4.5 \mathrm{~g}$, 28\%). m. p. $234-235^{\circ} \mathrm{C}{ }^{1} \mathrm{H}-\mathrm{nmr}$ : $2.65\left(3 \mathrm{H}, \mathrm{s}, \mathrm{CH}_{3}\right), 4.34(5 \mathrm{H}, \mathrm{s}, \mathrm{Cp}$ ' and $1 \mathrm{H}, \mathrm{s}, \mathrm{Cp}), 4.66(3 \mathrm{H}, \mathrm{s}$, $\mathrm{Cp}), 3.70\left(3 \mathrm{H}, \mathrm{s}, \mathrm{CH}_{3} \mathrm{O}\right), 7.13-7.46(10 \mathrm{H}, \mathrm{m}$, aromatic proton).Found: $\mathrm{C}, 73.07 ; \mathrm{H}, 4.39 \%$. $\mathrm{C}_{29} \mathrm{H}_{22} \mathrm{O}_{3} \mathrm{Fe}$ requires: $\mathrm{C}, 73.42 ; \mathrm{H}, 4.64 \%$. m/z, 474 .

\subsection{X-Ray analysis}

A dark purple crystal with dimensions $0.483 \times 0.260 \times 0.188 \mathrm{~mm}^{3}$ was placed and optically centered on the Bruker SMART CCD system at $-80^{\circ} \mathrm{C}$. The initial unit cell was indexed using a least-squares analysis of a random set of reflections collected from three series of $0.3^{\circ}$ wide $\omega$ scans ( 25 frames/series) that were well distributed in reciprocal space. Data frames were collected [MoK $\alpha$ ] with $0.3^{\circ}$ wide $\omega$-scans, 30 seconds/frame, 606 frames per series. Five complete series were collected, including an additional partial, first 160 frames, run of the first series for decay purposes, with a crystal to detector distance of $4.94 \mathrm{~cm}$, thus providing a complete sphere of data to $2 \theta_{\max }=55^{\circ}$. A total of 30967 reflections was collected and corrected for Lorentz and polarization effects and absorption using Blessing's method as incorporated into the program SADABS (Blessing 1995 and Sheldrick 1996) with 5041 unique [R(int)=0.0273].

\section{Results and Discussion}

Stobbe condensation of benzophenone and dimethyl succinate in the presence of potassium $t$ butoxide in toluene and subsequent methylation of the condensation product gave dimethyl (diphenylmethylene)succinate 4. A second Stobbe condensation using acetyl ferrocene yielded the half-ester, which was hydrolysed and cyclised using acetyl chloride, to afford solely fulgide 7 as dark purple crystals in $30 \%$ yield (Scheme 2 ).

Irradiation of fulgide 7 reveals no changes in wavelengths of absorption bands located at $\lambda_{\max }$ 392 and $544 \mathrm{~nm} \& 11300,3940 \mathrm{dm}^{3} . \mathrm{ml}^{-1} . \mathrm{cm}^{-1}$ respectively. This may indicate that there is neither $E / Z$ isomerisation, nor electrocyclic ring closure taking place in this specific fulgide, as normally seen in simple fulgides (Yokoyama 2000) (Scheme 3):

The structure and stereochemistry of fulgide 7 was confirmed by X-ray crystallographic analysis which is shown in Figure 1. Of particular interest in this fulgide are the following features:

- The phenyl rings and the ferrocenyl moiety are rotated from the plane of the anhydride ring.

- $\quad$ The angle CT2-Fe-CT1 is $177.46(8)$ and is less than the expected by $2.54^{\circ}$. 


\section{SYNTHESIS AND CRYSTAL STRUCTURE}

- The single bond C11-C12 (1.509 $\AA)$ is longer than the single bond C10-C11 (1.457 $\AA)$, while the single bonds $\mathrm{C} 17-\mathrm{C} 18$ and $\mathrm{C} 17-\mathrm{C} 24$ have almost the same length 1.489 and 1.484 $\AA$, respectively.

Selected bond lengths and angles are given in Table 1.

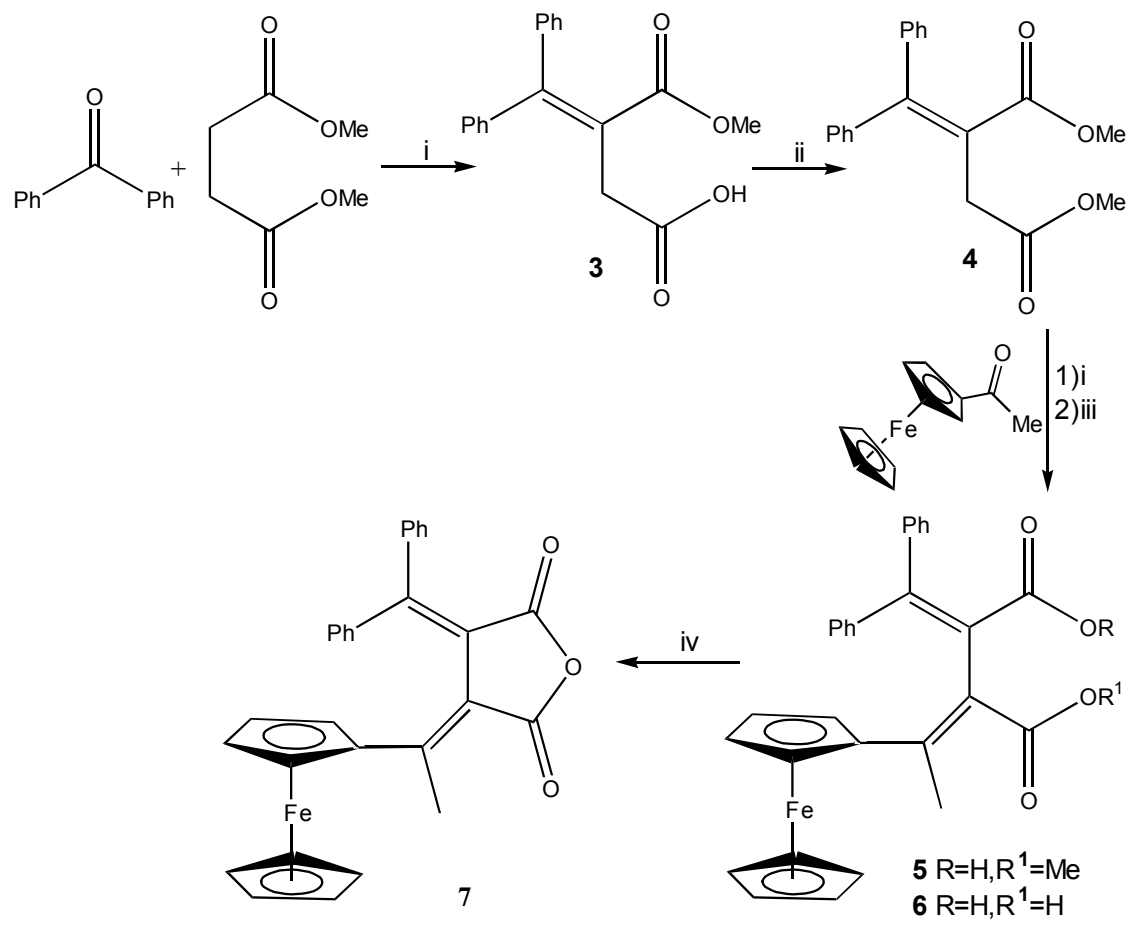

Scheme 2 : Reagents: $\mathrm{i}=t$-ButOK, toluene, $\mathrm{ii}=\mathrm{MeOH}, \mathrm{H}^{+}$, iii $=\mathrm{KOH}, \mathrm{iv}=\mathrm{CH}_{3} \mathrm{COCl}$.

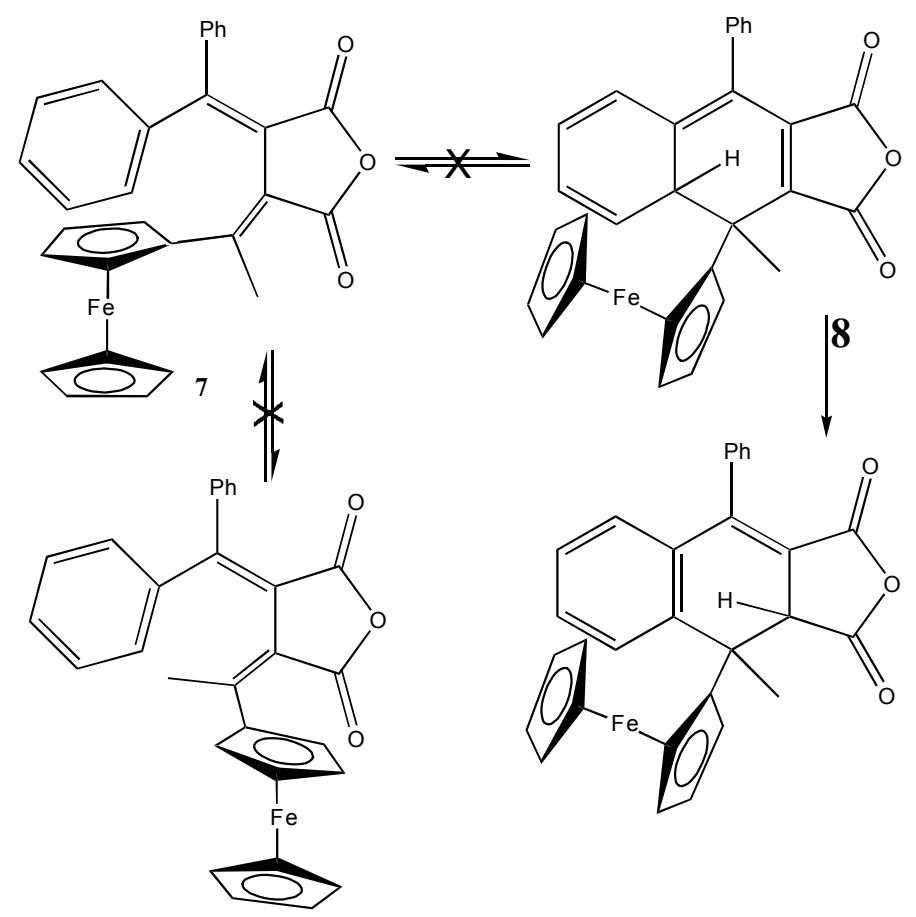

Scheme 3: Irradiation of 7 shows neither $E / Z$ isomerization, nor ring closure. 


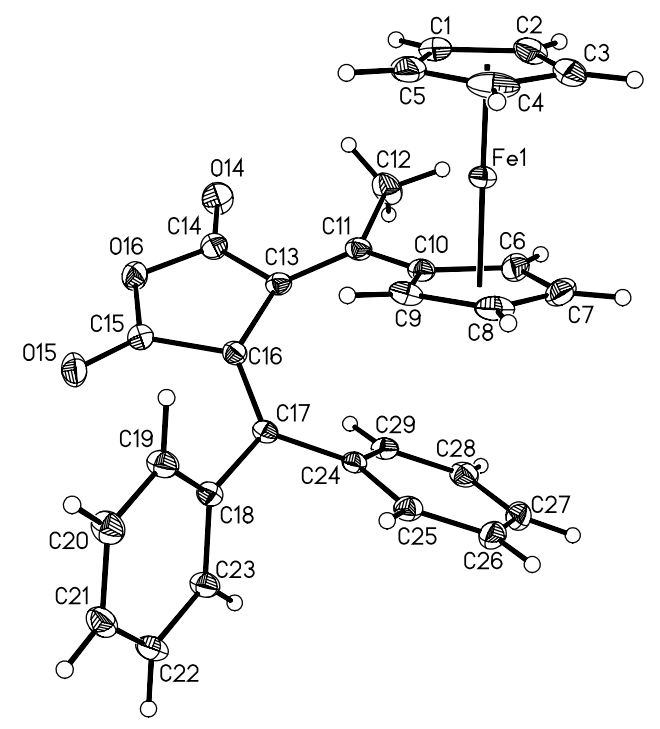

Figure 1. The molecular structure of 7 with the atom-numbering scheme. Hydrogen atoms are drawn as circles of arbitrary small radii for clarity.

Table 1 : Selected bond lengths $(\AA)$ and bond angles $\left(^{\circ}\right)$ for fulgide 7.

\begin{tabular}{lr}
\hline $\mathrm{Fe}(1)-\mathrm{CT} 2$ & $1.647(2)$ \\
$\mathrm{Fe}(1)-\mathrm{CT} 1$ & $1.661(2)$ \\
$\mathrm{C}(10)-\mathrm{C}(11)$ & $1.457(2)$ \\
$\mathrm{C}(11)-\mathrm{C}(13)$ & $1.371(2)$ \\
$\mathrm{C}(11)-\mathrm{C}(12)$ & $1.509(2)$ \\
$\mathrm{C}(13)-\mathrm{C}(16)$ & $1.474(2)$ \\
$\mathrm{C}(16)-\mathrm{C}(17)$ & $1.367(2)$ \\
$\mathrm{CT} 2-\mathrm{Fe}(1)-\mathrm{CT} 1$ & $177.46(8)$ \\
$\mathrm{C}(9)-\mathrm{C}(10)-\mathrm{C}(11)$ & $128.40(15)$ \\
$\mathrm{C}(13)-\mathrm{C}(11)-\mathrm{C}(10)$ & $123.08(14)$ \\
$\mathrm{C}(13)-\mathrm{C}(11)-\mathrm{C}(12)$ & $120.29(15)$ \\
$\mathrm{C}(10)-\mathrm{C}(11)-\mathrm{C}(12)$ & $116.63(14)$ \\
$\mathrm{C}(11)-\mathrm{C}(13)-\mathrm{C}(16)$ & $131.62(14)$ \\
$\mathrm{C}(16)-\mathrm{C}(13)-\mathrm{C}(14)$ & $105.84(13)$ \\
$\mathrm{C}(17)-\mathrm{C}(16)-\mathrm{C}(13)$ & $130.84(14)$ \\
$\mathrm{C}(17)-\mathrm{C}(16)-\mathrm{C}(15)$ & $121.73(14)$ \\
$\mathrm{C}(16)-\mathrm{C}(17)-\mathrm{C}(24)$ & $121.91(13)$ \\
$\mathrm{C}(16)-\mathrm{C}(17)-\mathrm{C}(18)$ & $122.11(14)$ \\
\hline
\end{tabular}

Structural determination and Refinement: All crystallographic calculations were performed on a Personal computer (PC) with dual Pentium 450MHz processors and 256MB of extended memory. The SHELXTL (Sheldrick 1994) program package was now implemented, XPREP, to determine the probable space group and set up the initial files. System symmetry and systematic absences 


\section{SYNTHESIS AND CRYSTAL STRUCTURE}

indicated the non-standard centrosymmetric space group $\mathrm{P} 2{ }_{1} / \mathrm{n}$ (no.14). The structure was determined by direct methods with the successful location of nearly all atoms using the program XS (Sheldrick 1990). The structure was refined with XL (Sheldrick 1993). After the initial refinement difference-Fourier cycle, additional atoms were located and input. After several of these refinement difference-Fourier cycles, all of the atoms were refined isotropically, then anisotropically. Hydrogen atoms were located directly from difference-Fourier maps and input; these atoms were freely refined. Centroids of the $\mathrm{Cp}$ rings were calculated. The final structure was refined to convergence $[\Delta / \sigma \leq 0.001]$ with $R(F)=3.91 \%, w R\left(F^{2}\right)=9.52 \%$, GOF $=1.060$ for all 5041 unique reflections $\left[R(F)=3.30 \%, w R\left(F^{2}\right)=8.87 \%\right.$ for those 4386 data with $\left.F_{o}>4 \sigma\left(F_{o}\right)\right]$. A final difference-Fourier map was featureless indicating the structure is therefore both correct and complete.

The function minimized during the full-matrix least-squares refinement was $\Sigma w\left(F_{o}^{2}-F_{c}^{2}\right)$ where $w=1 /\left[\sigma^{2}\left(F_{o}^{2}\right)+\left(0.0517^{*} P\right)^{2}+1.0474 * P\right]$ and $P=\left(\max \left(F_{o}^{2}, 0\right)+2 * F_{c}^{2}\right) / 3$. An empirical correction for extinction was attempted but found to be negative and therefore not applied.

\section{Crystal data for fulgide 7}

Empirical formula:

Formula weight

Temperature

Wavelength

Crystal system

Space group

Unit cell dimensions

Volume

Z

Density (calculated)

Absorption coefficient

$\mathrm{F}(000)$

Crystal size

Theta range for data collection

Index ranges

Reflections collected

Independent reflections

Completeness to theta $=27.50^{\circ}$

Absorption correction

Max. and min. transmission

Refinement method

Data / restraints / parameters

Goodness-of-fit on $\mathrm{F}^{2}$

Final $R$ indices [I $>2 \operatorname{sigma}(\mathrm{I})]$

$\mathrm{R}$ indices (all data)

Largest diff. peak and hole

$$
\begin{array}{ll}
\mathrm{C}_{29} \mathrm{H}_{22} \mathrm{FeO}_{3} & \\
474.32 & \\
193(2) \mathrm{K} & \\
0.71073 \AA & \\
\text { Monoclinic } & \\
\mathrm{P} 2(1) / \mathrm{n} & \\
\mathrm{a}=9.6446(10) \AA & \alpha=90^{\circ} . \\
\mathrm{b}=12.0427(12) \AA & \beta=90.183(2)^{\circ} . \\
\mathrm{c}=19.1244(19) \AA & \gamma=90^{\circ} .
\end{array}
$$

2221.2(4) $A$

4

$1.418 \mathrm{Mg} / \mathrm{m}^{3}$

$0.709 \mathrm{~mm}^{-1}$

984

$0.13 \times 0.210 \times 0.424 \mathrm{~mm}^{3}$

2.00 to $27.50^{\circ}$.

$-12<=\mathrm{h}<=12,-15<=\mathrm{k}<=15,-24<=\mathrm{l}<=24$

30967

$5041[R($ int $)=0.0273]$

$99.0 \%$

$S A D A B S$

1.000000 and 0.895124

Full-matrix least-squares on $\mathrm{F}^{2}$

5041 / 6 / 392

1.060

$R 1=0.0330, w R 2=0.0887$ [4386 Data]

$R 1=0.0391, w R 2=0.0952$

0.351 and -0.248 e.

\section{Acknowledgements}

The author would like to thank Dr. J. Fitteger, X-Ray Crystallographic Facility, Chemistry and Biochemistry College Park, University of Maryland, USA, for carrying out the x-ray performance. 


\section{SHAR SAAD AL-SHIHRY}

\section{References}

BLESSING, R.H. 1995. An empirical correction for absorption anisotropy. Acta Crystallographica. A51: 33-38.

HART, R.J. and HELLER, H.G. 1972. Overcrowded Molecules. Part VII. Thermal and Photochemical Reactions of Photochromic (E)- and (Z)Benzylidene(diphenylmethylene)succinic Anhydrides and Imides. Journal of the Chemical Society, Perkin Transactions, 1: 1321-1324.

HELLER, H.G. 1978. The development of photochromic compounds for use in optical information stores. Chemistry and Industry, 18 March. 193-196.

LIANG, Y., DVORNIKOV, A.S. and RENTZEPIS, P.M. 2001. Photochemistry of photochromic 2 -indolylfulgides with substituents at the 1'-position of the indolylmethylene moiety. Journal of Photochemistry and Photobiology A: Chemistry, 146( 1): 83-93 (11).

McCABE, R.W., PARRY, D.E. and SABERI, S.P. 1993. Organometallic Fulgides. Part 1. Synthesis and Photochemistry of Ferrocenyl Fulgides [Ferrocenylethylidene (isopropylidene)succinic Anhydrides]. Journal of the Chemical Society, Perkin Transactions, 1: 1023-1029.

SHELDRICK, G.M., 1996. SADABS ‘Siemens Area Detector Absorption Correction' University of Göttingen: Göttingen, Germany.

SHELDRICK, G.M., 1994. SHELXTL/PC. Version 5.03. Siemens Analytical X-ray Instruments Inc., Madison, Wisconsin, USA.

SHELDRICK, G.M., 1993. Shelx193 Program for the Refinement of Crystal Structures. University of Göttingen, Germany.

SHELDRICK, G.M., 1990. Phase annealing in SHELX-90: direct methods for larger structures. Acta Crystallographica. A46: 467-473.

YOKOYAMA, Y., 2000. Fulgides for memories and switches. Chem. Rev. 100(5): 1717-1739.

Received 29 April 2003

Accepted 24 June 2003 